\title{
Donald Kagan: A Citizen Scholar
}

\section{Steve Balch}

Were academe a polis Donald Kagan would stand as one of its ideal, allaround citizens, here debating with his fellows in the agora, there leading them in ranks against the forces of dullness and ignorance, sometimes tilling the fields of historical scholarship, at others helping youth prepare for their participation in the upcoming municipal games. Such was the life of the giant of scholarship who left this world, aged eighty-nine, on August $6^{\text {th }} 2021$.

As a scholar Don will probably be best remembered for his comprehensive study of the Peloponnesian War, the definitive modern update on the work of Thucydides, who like Kagan also thought, wrote, and fought. As a university leader Don's moment arrived in 1989 when he became Dean of Yale College and in the face of fierce faculty opposition sought to enrich its curriculum and overhaul its very creaky organizational structure. He also once held the post, ad interim, of Director of Athletics (he was after all a history teacher!) overseeing, à la the Greeks, the cultivation of a sound body to house a similarly trained mind. (As Master of Timothy Dwight College he had actually butted heads with rival colleagues in intramural sports.) On the Yale campus, however, he was best renowned as a legendary teacher, whose gripping courses were a must for even less serious students.

Don first came to general public notice as a great champion of the centrality of Western civilization's place in the university curriculum, starting at Yale and then launching into the larger world of American letters. The least of this, but still dear to me, involved his answering my call when the NAS first formed and coming on its advisory board-inviting me to join him at a table down at Mory's, not to listen to the Whiffenpoofs, but to descant upon the deformities of university life and what was needed to be done to correct them.

It is to be lamented that Don didn't see the reforms that he and President Benno Schmidt wanted implemented. The faculty abhorred any straitening of

Steve Balch was the Founding President of the National Association of Scholars; Steve.Balch@ttu.edu. 
their budgets, even though Yale, at the time, was deep in the red. So with Kagan and Schmidt's departures, a grand opportunity to pioneer a revival in the teaching of Western civilization through an integrated (though optional) undergraduate curriculum was lost. Those departures also set the stage for one of American academe's most notorious cause célèbres, the return of a $\$ 20,000,000$ gift by Yale to alumnus and donor Lee Bass. Bass had lost faith that Kagan and Schmidt's successors would use his gift according to its intent, that is to say, the creation of a paragon program reflecting Western civilization's historic genius.

At an NAS conference, where he had been honored with the Sidney Hook Memorial Award, Don made clear why he believed that the study of the West deserved pride of place in the university curriculum.

The civilization of the West ... was not the result of some inevitable process through which other cultures will automatically pass. It emerged from a unique history in which chance and accident often played a vital part. The institutions and ideas that therefore provide for freedom and improvement in the material conditions of life cannot take root and flourish without an understanding of how they came about and what challenges they have had to surmount. Non-Western people who wish to share in the things that characterize modernity will need to study the ideas and history of Western civilization to achieve what they want and Westerners who wish to preserve them must do the same.

I've often echoed these words myself and they continue to give the work of the National Association of Scholars much of its direction.

Like the Greeks, Donald Kagan realized that the well-lived life, and thus a well-grounded education had, as much as possible, to involve the unremitting pursuit of excellence. Because the Greeks, again like Kagan, also realized that excellence could never be achieved without competition, they gave almost everything a competitive spin, whether it be athletic skill, oratory, or playwriting. In their world excuses never won laurels.

Kagan was among the first to recognize the devolution of academic culture wherein competitive meritocracy was replaced with diverse meretriciousness, particularly in the humanities. Although in most ways the consummate humanist, a man disposed to gaining universal perspectives and rendering qualitative judgments, he could see that in a time of intellectual decay, it was the natural 
sciences that constituted rigor's last bastion and its failsafe source of succor for weak and erring disciplinary sisters. One of his reasons for becoming a dean was to call upon them to redress humanism's decline at Yale. As he observed at another NAS conference:

One of the things I've tried to do in the short time I've been dean is to support, foster, and extend the study of the natural sciences at Yale. Now, heaven knows, simply for balance Yale needs that more than most places because we're so top heavy in the humanities. But there's more to it than that. In my judgment, the natural sciences are the healthiest of the disciplines taught at our universities. I don't know a single natural scientist who does not believe in the efficacy of reason, or the possibility of truth arrived at through reason. On the other hand, the woods are full of humanists who doubt those things . . . You have to help the natural scientists understand what's happening in the humanities and why it matters to them enormously. What's more, you have to involve them in the total life of the institution and ask their help in defending reason and the search for truth.

The reader of course knows that this also didn't happen at Yale. Thirty years later it clearly hasn't happened elsewhere either. With the steady "awokening" of the natural sciences, the situation has in fact been moving steadily in the other direction. Don's fight thus proved less a Salamis than a Chaeronea, the world of the academic poleis overrun by crude barbarism. It wasn't that Don flinched or didn't understand the nature of the combat. He left his decanal post in a cloud of Homeric glory. But even Leonidas, in delaying the Persians at Thermopylae, needed 299 other stalwarts, not anything that Yale, even then, could have offered.

That said, Don didn't fail. The Athenian polis is also gone, very long gone, but one can't say it failed either. We still remember its noblest citizens for the illustrations they gave on how to live, learn, and sacrifice. Don is now among them, and his example won't be lost as well. 